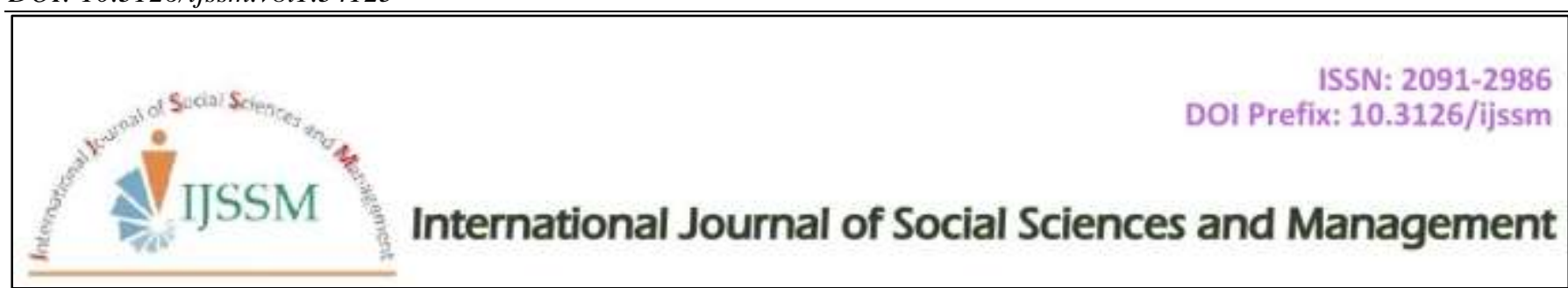

Research Article

\title{
Attitude of Student Professionals towards Persons with Disabilities
}

\author{
Hilalulla K.B. ${ }^{1}$, Arul Actovin C. ${ }^{*}$., Prasath Selvaraj ${ }^{1}$ \\ ${ }^{1}$ Department of Social Work, Pondicherry University, Puducherry - 605 014, India
}

\begin{tabular}{|c|c|}
\hline Article Information & bstract \\
\hline $\begin{array}{l}\text { Received: } 29 \text { November } 2020 \\
\text { Revised version received: } 05 \text { January } 2021 \\
\text { Accepted: } 08 \text { January } 2021 \\
\text { Published: } 25 \text { January } 2021 \\
\text { Cite this article as: } \\
\text { Hilalulla K.B. et al. (2021) Int. J. Soc. Sc. Manage. } \\
\text { 8(1): 306-311. DOI: } 10.3126 / \text { ijssm.v8i1.34125 } \\
\text { *Corresponding author } \\
\text { Arul Actovin C., } \\
\text { Department of Social Work, Pondicherry University, } \\
\text { Puducherry - 605 014, India } \\
\text { Email: arulactovin @ gmail.com } \\
\text { Peer reviewed under authority of IJSSM } \\
\text { (C) } 2021 \text { IJSSM, Permits unrestricted use under the } \\
\text { CC-By-NC license. } \\
\text { OPEN } 0 \text { ACCESS } \\
\text { This is an open access article \& it is licensed under a } \\
\text { Creative Commons Attribution Non-Commercial } 4.0 \\
\text { International } \\
\text { (https://creativecommons.org/licenses/by-nc/4.0/) }\end{array}$ & $\begin{array}{l}\text { The research focused on students who are pursuing their final year in three different } \\
\text { professional courses- Master of Social Work, Bachelor of Education, and Bachelor } \\
\text { of Nursing at three different educational institutions in Puducherry. This study } \\
\text { adopted a descriptive research design and used interaction with a disable person } \\
\text { (IDP) scale to understand the attitude of student professionals toward persons with } \\
\text { disabilities and also to find what influences the attitude of future professionals. The } \\
\text { primary aim is to learn more about the way students of three different professions } \\
\text { generally view persons with disabilities and feel about interacting with this } \\
\text { population. The interaction and attitude will create an impact on their practice of } \\
\text { the profession in the future. The findings indicate that the students of three different } \\
\text { professions were having a negative attitude towards PWDs but no significant } \\
\text { difference was found in gender, locality, and course of study. Results also enlighten } \\
\text { the educators, health professionals and non-governmental organizations to plan } \\
\text { programs that shall create changes in the attitude of students towards PWDs. This } \\
\text { research concludes with reflections on the need to revive the social interaction of } \\
\text { student professionals with persons with disabilities. }\end{array}$ \\
\hline & \\
\hline
\end{tabular}

\section{Introduction}

A person's life is a product and part of the larger social structure and the persons with disabilities are no longer different. Their relationship, disposition, and personal conduct standards are imperatively influenced by the content and degree of the harmony with the family persons, companions, relatives, work environment partners, and so on. Certainly, the disabled persons face serious problems in the societal attitude and approach than in their disability (Sofi \& Cherian, 2014). A greater concern both from the global and national stakeholders towards the persons with disabilities is reflected in the structuring and policing of the Sustainable Development Goals (SDGs). With the aim of 'leaving no one behind' and 'inclusive action', the 2030 agenda of global goals has adopted SDG 10 - "Emphasizing the social, economic and political inclusion of persons with disabilities" and SDG 11 - "Creating accessible cities and water resources, affordable, accessible and sustainable transport systems"(Social Statistics Division, 2016).

The world's largest groups of minorities are persons living with disabilities. This community estimates over a billion 
population that corresponds to be around 15 percent of the entire global accommodate (World Health Organisation, 2020). Subsequently, eighty percent of the disabled persons are known to reside in the developing nations (United Nations, 2018). In India, the latest survey conducted from July 2018 to December 2018 claimed the prevalence of disability around 2.2 percent with a higher disability among males than females. Likewise, the state-wise distinction showed a higher percentage of males (58.1 percent) from Puducherry with a certificate of disability that reveals their rate of disability to be over 40 percent (National Statistical Office, 2018). As a result of this growing disabled population at the global, national, and regional spaces, the need for health care professionals in providing necessary services to the disabled becomes paramount. Being key service providers, health care professionals are likely to have higher contact with the disabled persons resulting in their physical, emotional, and mental well-being (Awoyera, 2011).

In general, the communication problem, poor rapport with health care professionals, insufficient information and guidance, inadequate internal care, and lack of personal care service affects and delays any diagnosis and treatment (Mantziou et al., 2002). Relatively, persons with disabilities (PWDs) are sought to seek more health care services than anyone. Undermining their expectation, most of the time their greater needs are unmet. Besides, the PWDs are multiple times liable to report being dealt badly and almost multiple times bound to report being denied health services. For example, an overview of people with genuine mental issues stressed that somewhere in the range of 76 and 85 percent of people living in developing countries have not received any treatment in the year before the study (World Health Organisation, 2020). There has additionally been a higher report on the adverse encounters among the disabled people in their communications with health care experts from various professional backgrounds. The nursing profession as an aggregate appears to be quiet in this perspective (Smeltzer, 2007). Article 25 of the United Nations Convention on the Rights of Persons with Disabilities (CRPD) supports the privilege of PWDs to get the best calibre of medicinal services, with no discrimination (World Health Organisation, 2009). Perspectives toward disabilities reflect convictions about PWDs and as such guide towards the same (Roberts \& Smith, 1999). To control and overcome the situation, more knowledge is needed on the present status of the interactions and attitudes of future health care professionals towards PWDs. In the Indian context, this area is reported to be less likely studied and this research study addresses the gap.

\section{Aims and Objectives}

The key objective of the research study is to understand respondents' interaction towards PWDs in Puducherry The specific objective of the research study as follows.
1. To find out the socio-demographic profile of the respondents.

2. To understand respondents' interaction towards PWDs.

\section{Materials and Methods}

The study focused on students pursuing three different professional courses namely Social work, Education, and Nursing belonging to three different educational institutions in Puducherry. A descriptive research design is used in this study by the researchers. The researchers used interaction with a disable person (IDP) scale which is a 20-point Likert scale designed to assess 'attitude towards persons with disabilities' by examining social interaction levels of discomfort as a key factor driving negative attitudes (Gething, 1992). A structured statistical data sheet was used to obtain variables. The sample size of the research study was one hundred and fifty and the researchers have selected fifty respondents randomly from every three different educational institutions respectively. Descriptive statistics were analysed to know the respondents' interaction with disabled persons. The researchers systematically followed research ethics during the entire course of the study. The respondents were informed about the main purpose of the current study. Written and oral informed consent has been taken from all the respondents.

\section{Results}

The current status of respondents' interaction with disabled persons was analysed from the primary sources collected from the field.

\section{Socio-Demographic Profile}

The Table 1 shows the demographic profile of the participants, which revealed that nearly four fifths of them $(79.33 \%)$ were female and little more than half $(52.67 \%)$ of the respondents were in the age group of twenty-one years to twenty-five years. Also, less than half (44.00\%) of the respondents were in the age group of fewer than twenty years. More than half $(57.33 \%)$ of the respondents were living in urban areas and less than half $(42.67 \%)$ of them belong to rural areas.

\section{Interaction with Persons with Disability}

Table 2 clearly shows that little more than half of the respondents had negative interaction towards persons with disabilities and little more than one tenth of the respondents had positive interaction as well as little less than two fifths of respondents' interaction had no difference with persons with disability.

From Table 3, it is clear that there is no significant difference among the respondents' interaction towards persons with disabilities based on gender and their locality. The current education curriculum may influence respondents to gender and locality differences. 
Hilalulla K.B. et al. (2021) Int. J. Soc. Sc. Manage. Vol. 8, Issue-1: 306-311

The Table 5 shows that the interaction of respondents with the disabled person was medium and there is no significant difference between the course of study and interaction of respondents with disable persons $(\mathrm{t}(149)=1.158, \mathrm{p}=0.262$ $>0.05)$
A Chi-square test is showed for the profile to analyse if there is a difference between the two gender groups, locality, and course of study. Statistically not significant $(p=0.849,0.694,0.749)$ results of chi-square indicate that profile preference no differs through gender, locality, and course of study.

Table 1: Socio-Demographic Profile of the respondents

\begin{tabular}{|c|c|c|c|c|}
\hline \multicolumn{2}{|l|}{ Variables } & Gender & Number & Total (percent \%) \\
\hline \multirow{4}{*}{ Locality } & \multirow{2}{*}{ Rural } & Male & 14 & \multirow{2}{*}{$64(42.67 \%)$} \\
\hline & & Female & 50 & \\
\hline & \multirow{2}{*}{ Urban } & Male & 17 & \multirow{2}{*}{$86(57.33 \%)$} \\
\hline & & Female & 69 & \\
\hline \multirow{6}{*}{ Age } & \multirow{2}{*}{ Below 20 Years } & Male & 13 & \multirow{2}{*}{$66(44.00 \%)$} \\
\hline & & Female & 53 & \\
\hline & \multirow{2}{*}{21 to 25 Years } & Male & 15 & \multirow{2}{*}{$79(52.67 \%)$} \\
\hline & & Female & 64 & \\
\hline & \multirow{2}{*}{26 to 30 Years } & Male & 3 & \multirow{2}{*}{$5(03.33 \%)$} \\
\hline & & Female & 2 & \\
\hline \multirow{6}{*}{ Course of Study } & \multirow{2}{*}{ Master of Social Work } & Male & 11 & \multirow{2}{*}{$50(33.33 \%)$} \\
\hline & & Female & 39 & \\
\hline & \multirow{2}{*}{ Bachelor of Education } & Male & 19 & \multirow{2}{*}{$50(33.33 \%)$} \\
\hline & & Female & 31 & \\
\hline & \multirow{2}{*}{ Bachelor of Nursing } & Male & 1 & \multirow{2}{*}{$50(33.33 \%)$} \\
\hline & & Female & 49 & \\
\hline \multirow{2}{*}{\multicolumn{2}{|c|}{ Total }} & Male & 31 & \multirow{2}{*}{$150(100 \%)$} \\
\hline & & Female & 119 & \\
\hline
\end{tabular}

Source: Primary Data

Table 2: Respondents interaction with persons with disability

\begin{tabular}{|l|l|l|}
\hline S.N. & Level & Number (Percent \%) \\
\hline 1 & High & $26(17.33 \%)$ \\
\hline 2 & Medium & $92(61.33 \%)$ \\
\hline 3 & Low & $32(21.33 \%)$ \\
\hline Total & $150(100.00 \%)$ \\
\hline
\end{tabular}

Source: Primary Data

Table 3: Independent Samples Test for gender, locality, and interaction with disabled persons

\begin{tabular}{|l|l|l|l|l|l|l|l|}
\hline S.N. & Gender & Frequency & Mean & Std. Deviation & t & df & Sig. (2-tailed) \\
\hline \multirow{2}{*}{ Gender } & Male & 31 & 66.0629 & 10.47104 & \multirow{2}{*}{144} & \multirow{2}{*}{148} & .810 \\
& Female & 119 & 66.5761 & 10.60876 & -.241 & & \\
\hline \multirow{2}{*}{ Locality } & Rural & 64 & 2.9844 & .57714 & .412 & 148 & .681 \\
& Urban & 86 & 2.9419 & .65717 & & & \\
\hline
\end{tabular}

Table 4: Anova Test for the course of study and interaction with disabled persons of respondents

\begin{tabular}{|l|l|l|l|l|l|}
\hline & Sum of Squares & df & Mean Square & F & Sig. \\
\hline Between Groups & 32.667 & 44 & .742 & 1.158 & .269 \\
\hline Within Groups & 67.333 & 105 & .641 & & \\
\hline Total & 100.000 & 149 & & & \\
\hline
\end{tabular}


Table 5: Chi-square test

\begin{tabular}{|c|c|c|c|c|c|c|}
\hline & \multicolumn{3}{|c|}{ Level of interaction with disable person } & \multirow[t]{2}{*}{ Chi-square value } & \multirow[t]{2}{*}{ Sig. } \\
\hline & & Positive & Indifference & Negative & & \\
\hline \multirow[t]{2}{*}{ Gender } & Male & 4 & 10 & 17 & \multirow[t]{2}{*}{0.327} & \multirow[t]{2}{*}{0.849} \\
\hline & Female & 14 & 45 & 60 & & \\
\hline \multirow[t]{2}{*}{ Locality } & Rural & 6 & 24 & 34 & \multirow[t]{2}{*}{0.732} & \multirow[t]{2}{*}{0.694} \\
\hline & Urban & 12 & 31 & 43 & & \\
\hline \multirow{3}{*}{$\begin{array}{l}\text { Course of Study } \\
\text { (Final year) }\end{array}$} & B. Sc Nursing & 8 & 17 & 25 & \multirow[t]{3}{*}{1.926} & \multirow[t]{3}{*}{0.749} \\
\hline & MSW & 6 & 20 & 24 & & \\
\hline & B. Ed & 4 & 18 & 28 & & \\
\hline \multicolumn{2}{|l|}{ Total } & 18 & 55 & 77 & & \\
\hline
\end{tabular}

\section{Discussion}

Disability is an emerging and dynamic condition in which strategy and social norms decide people's opportunities (Hallahan, 2010). The disability is considered as a saddle and the burdening of disability results in the low social inclusion and low social participation of persons with disabilities. The understanding of disability is a collection of interactions instead of being a chronic illness needing medical intervention (Munford \& Bennie, 2015). In developing countries, PWDs are often stigmatized, discriminated against, socially excluded from community life, and poverty-stricken (World Health Organisation \& World Bank, 2011). The people's interaction with PWDs has a vital role in the improvement of the disability community as well as people's relationship with PWDs is a significant factor and an open attitude towards PWD's life to become part of the society. Kim and his colleagues (2010) found that health care professionals have a negative attitude toward PWDs. The study conducted in Sweden by Högberg (2010) also highlights the reality of negative attitudes among mental health professionals toward PWDs. Negative attitudes may result in social rejection, social isolation, reduced self-esteem, and maintenance of higher levels of social distance towards PWDs (Chen et al., 2011).

The current study focusing on the nature of contact with PWDs of upcoming professionals related to disabilities, who are yet to become social workers, nurses, and teachers. The study also reveals that more than half of the respondents have a negative interaction with PWDs. The study investigated the attitude of nursing students in Greece toward disabled children shows that there was a poor attitude among the nursing student (Mantziou et al., 2002). The level of academics affects the students' attitudes of persons with disabilities in nursing students. Understanding the knowledge of nursing will influence the formation of attitude. The higher the academic level will create a higher attitude among students (A'la et al., 2018).

Teachers with a positive attitude are readily changing and adapting the ways they work together to help students a variety of learning needs (Sharma et al., 2006; Subban \&
Sharma 2005). Such teachers also have a strong impact on their colleagues' attitudes towards students with disabilities (Nowicki \& Sandieson 2002). The most significant factors for children with special needs are teacher's attitude and it has influence in children's education (Smith, 2000). Several studies (Avramidis \& Norwich, 2002; Forlin, 2001) have concluded that successful adoption of inclusion policies primarily depends on the educators' goodwill. Social workers often take the time to consider the sense processes of people with learning disabilities by developing an awareness of how their everyday life experiences are influenced by various factors and those are social, economic, political, cultural, and religious factors affect and change daily life. These examining that they have limited or opened up opportunities for the PWDs (Munford \& Sanders, 2008).

The social workers, nurses, and the teachers are the key service providers for the person with disabilities. These professionals have a vital role in reducing stigma and discrimination among PWDs. The negative interactive experience of the students toward PWDs has to be resolved. Promoting the positive interactions toward PWDs will contribute to the anti-stigma efforts of rehabilitation professionals. Morrison (2005) suggests the need for disability information and education to enhance social workers' ability to practice in a manner that benefits PWDs. The educational interventions have to be designed which focuses on forms of experiences outside the setting of formal care relationships. The government has to take a necessary step with the help of educational institutions or schools to provide experiential learning by allowing interacting with PWDs at a young age. The engagement with PWDs will develop in a positive sense of feeling. Scacco and Warren (2018) in their experimental research conducted in Nigeria signify the relationship between positive social contact and discrimination. They show that positive social contact increases in kindness and decreases in the discriminatory behaviour of the participants of the study. The educational institutions have to set opportunities 
to students for positive social interaction with PWDs in terms of workshops or field visits.

The intervention study done among students to address the negative attitude toward people with psychosocial disabilities suggest that positive changes can happen through short educational workshops (Pinfold et al., 2003). The formation of the attitude of an individual toward a group of people influenced by personal experience, influence of family and friends, and from mass media. People grow through interaction with the world. The interaction leads us to learn to categorize, discriminate, and generalize (Siegler \& Alabali, 2005). Whitehead (2001) explains the implications of the process of thinking together which will influence developing our social consciousness. Engagement with persons with disabilities and thinking together can observe the individual's preconceptions, stereotypes, and prejudices toward PWDs. The social consciousness about PWDs has to be developed through positive interactions and experiences in the community. It will result in better social participation of persons with disabilities.

\section{Conclusion}

The study provides a platform to explore the attitude and interactions of upcoming health care professionals, social workers and teachers towards PWDs. As a result, the findings of the study reveal a significant relation in the attitude of future social workers, special educators, and nurses in their interaction with the disabled persons. With no secondary thought, the study involved poses an urgent call to the government and educational institutions to examine the prevailing problem and take necessary action at the institutional, regional, and national scale. Moreover, the inclusion of maintaining the dignity of disabled persons in the course content of the health care professionals, developing interventions, and educating them to address the same shall pave a healthy way forward to encourage and sustain a friendly relationship between the health professionals and the disabled.

\section{Authors' Contributions}

All the authors were involved during the conceptualization and write up of the article. Final form of the manuscript was approved by all authors

\section{Conflict of Interests}

The authors declare that there is no potential conflict of interest with respect to this paper.

\section{References}

A'la MZ, Setioputro B \& Kurniawan DE (2018) Nursing Students' Attitudes towards Caring for Dying Patients. Nurse Media Journal of Nursing 8(1): 25-34.

Avramidis E and Norwich B (2002) Teachers' attitudes towards integration/inclusion: A review of the literature. European
Journal of Special Needs Education 17(2): 129-147.

Chen S, Ma L \& Zhang JX (2011) Chinese Undergraduates' Explicit and Implicit Attitudes Toward Persons with Disabilities. Rehabilitation Counseling Bulletin 55(1): 3845.

Forlin C (2001) Inclusion: identifying potential stressors for regular class teachers. Educational Research 43(3): 235245. https://doi.org/10.1080/00131880110081017

Gething L \& Wheeler B (1992) The interaction with disabled persons' scale: A new australian instrument to measure attitudes towards people with disabilities. Australian Journal of Psychology 44(2): 75-82. https://doi.org/10.1080/00049539208260146

Good T L \& Brophy JE (1991) Looking in classrooms (5th ed.). New York: Harper Collins.

Hallahan L (2010) Legitimising Social Work Disability Policy Practice: Pain or Praxis? Australian Social Work 63(1): 117-132. https://doi.org/10.1080/03124070903515458

Högberg T (2010) 'Not in my backyard': Public attitudes towards mental illness and people with mental illness living in sweden. Institutionen för klinisk neurovetenskap/Department of Clinical Neuroscience.

Kim K, Park YH, Lee BS \& Kim JY (2010) Comparison of the attitudes toward and contact with disabled person among health care professionals, lay persons, and disabled persons. Korean Journal of Rehabilitation Nursing 13(1): 13-22.

Mantziou V, Brocalaki I, Andrea S, Ktenas E, Chatira K \& Kotzabassak S (2002) Attitudes of registered nurses and student nurses to disabled children. British Journal of Nursing 11(17): 1141-1146. https://doi.org/10.12968/bjon.2002.11.17.1141

Morrison IA (2005) Attitude Change Among Undergraduate Rehabilitation Interns. Florida State University. http://purl.flvc.org/fsu/fd/FSU_migr_etd-2256

Munford R \& Bennie G (2015) Learning Disability and Social Work. International Encyclopedia of the Social \& Behavioral Sciences 684-689. https://doi.org/10.1016/b978-0-08-097086-8.28118-x

Munford R \& Sanders J (2008) Assessment of families. In: Rowe W, Rapp-Paglicci LA, Sowers KM and Dulmus CN (Eds.) Comprehensive handbook of social work and social welfare, Vol. 3. Social work practice (pp399-422). John Wiley \& Sons Inc. https://doi.org/10.1002/9780470373705.chsw003022

Nowicki EA \& Sandieson R (2002) A Meta-Analysis of SchoolAge Children's Attitudes Towards Persons with Physical or Intellectual Disabilities. International Journal of Disability, Development and Education 49(3): 243-265.

Pinfold V, Toulmin H, Thornicroft G, Huxley P, Farmer P, \& Graham T (2003) Reducing psychiatric stigma and discrimination: Evaluation of educational interventions in UK secondary schools. British Journal of Psychiatry 182(4): 342-346. 
Roberts CM \& Smith PR (1999) Attitudes and behaviour of children toward peers with disabilities. International Journal of Disability, Development and Education 46(1): $35-50$.

Scacco A \& Warren SS (2018) Can Social Contact Reduce Prejudice and Discrimination? Evidence from a Field Experiment in Nigeria. American Political Science Review 112(3): 654-677.

Sharma U, Forlin C, Loreman T \& Earle C (2006) Pre-service teachers' attitudes, concerns and sentiments about inclusive education: An international comparison of the novice pre-service teacher. International Journal of Special Education 21(2): 80-93.

Siegler RS \& Alibali MW (2004) Children's Thinking (4th Edition) (4th ed.). Prentice Hall.

Smeltzer SC (2007) Improving the health and wellness of persons with disabilities: A call to action too important for nursing to ignore. Nursing Outlook, 55(4). https://doi.org/10.1016/j.outlook.2007.04.001

Smith M (2000) Secondary teachers' perception toward inclusion of students with severe disabilities, National Association of Secondary School Principals (NASSP) Bulletin, 84(613): 54-60.
Social Statistics Division (2016) Disabled Persons in India: A Statistical Profile 2016. Social Statistics Division, Ministry of Statistics and Programme Implementation. http://mospi.nic.in/sites/default/files/publication_reports/ Disabled_persons_in_India_2016.pdf

Sofi UJ \& Cherian RM (2014) Social Exclusion of Disabled Persons in India and their Attitude Towards Society: A study of locomotor disables of Pondicherry. GRIN Verlag.

Subban P \& Sharma U (2005) Understanding educator attitudes toward the implementation of inclusive education. Disability Studies Quarterly 25(2): 1 - 19.

Whitehead C (2001) Social mirrors and shared experiential worlds, Journal of Consciousness Studies 8 (4): 3-36.

World Health organisation \& World Bank (2011) World Report on Disability. World Health Organisation. https://www.who.int/disabilities/world_report/2011/repor t.pdf

World Health Organisation (2020) Disability and health. https://www.who.int/en/news-room/factsheets/detail/disability-and-health

World Health Organization (2009) Mental health, poverty and development. Addressing noncommunicable diseases and mental health: major challenges to sustainable development in the 21 st century. 